\title{
Mare Migrantum: EU's pengediplomati i migrant- og flygtninge- politikken
}

\section{Af Peter Nedergaard}

Den Europæiske Union har altid anvendt pengeinstrumentet $i$ international politik. Det ligger $f x$ alene $i$, at EU med en udviklingsbistand på 82 mia. euro i perioden 2014-2020 står for ca. halvdelen af verdens samlede udviklingsbistand.

Der er imidlertid siden migrant- og flygtningekrisen 2015-16 sket en vis, mindre ændring med hensyn til anvendelsen af EU's eksterne midler fra officielt at være rettet næsten udelukkende mod idealistiske mål og til også at være rettet mod såkaldte realistiske mål.

Min prognose er, at denne udvikling vil forstærkes fremover, fordi pengediplomatiet realistisk anvendt har vist sig at være yderst effektivt. Sandsynligvis vil EU-landene med hensyn til EU's migrant- og flygtningepolitik være interesserede i en udvikling, hvor EU tvinges til at agere stadig mere realistisk i dets eksterne relationer på grund af et demografisk pres fra Afrika og fortsat uro i Mellemøsten samtidig med, at USA er ved at opgive verdenslederskabet.

Med idealisme mener jeg i den forbindelse, at EU's midler anvendes til at afhjælpe udviklingsproblemer i den tredje verden, at fremme menneskerettighederne, at udbrede demokratisk praksis og lignende. Man kan med en vis ret sige, at penge hertil er udtryk for udbredelsen af europæiske normer angående lighed, respekt for individet, ligestilling mellem $\mathrm{k} ø$ nnene med videre $i$ andre lande end EU-landene.

Med realisme mener jeg, at EU's midler går til formål, som angår fremme af EU's egne økonomiske og sikkerhedsmæssige interesser ud fra, hvordan vælgerne i EU's medlemslande ser på dem. Realismen i EU's pengediplomati indebærer således, at man fra EU's side vil have noget for noget,

Peter Nedergaard er professor i statskundskab ved Københavns Universitet. 
(2) Man kan med en vis ret sige, at penge hertil er udtryk for udbredelsen af europæiske normer angående lighed, respekt for individet, ligestilling mellem kønnene med videre i andre lande end EUlandene.

når det drejer sig om, at man anvender pengeudbetalinger uden for EU's grænser.

Idealismen betyder således, at EU's pengediplomati er rettet mod (i hvert fald officielt) behovene i modtagerlande, mens realismen (også officielt) afspejler EU's egne interesser.

I denne artikel diskuteres en række lande, som er relevante for EU's migrant- og flygtningepolitik. Det giver naturligvis en skævvridning $i$, hvor udbredt realismen er i EU's pengediplomati, idet området i høj grad tiltrækker realistiske overvejelser.

Realismen i de eksterne relationer på området afspejler således også modstanden internt i EU's medlemslande mod at tage flere migranter og flygtninge fra tredjeverdenslande.

Samtidig er den interne fordelingsmekanisme i EU med hensyn til flygtningene fra den tredje verden reelt brudt sammen. Dels er den såkaldte Dublin-mekanisme, der ellers betyder, at flygtninge i princippet skal sendes tilbage til asylbehandling i det EU-land, som de først ankom til, ringe fungerende. Det sker i dag kun for cirka 15 pct. af asylsøgerne ifølge Deutsche Welle fra 30. juni 2018. Dels er beslutningen om en forholdsmæssig og tvangsmæssig fordeling internt i EU af en vis mindre portion flygtninge på 160.000 kun i begrænset omfang blevet effektueret.

Derfor har en række EU-lande været interesseret $i$ et eksternt svar på migrant- og flygtningespørgsmålet via oprettelse af modtagelsescentre for migranter og flygtninge i Nordafrika (eller eventuelt i Europa uden for EU, hvor Albanien har været nævnt), fordi det har vist sig meget svært at finde løsninger, der er acceptable for vælgerne i EU's medlemslande, når først grænserne ind i EU er passeret.

I det følgende behandles EU's relationer til alle migrant- og flygtningerelevante lande rundt om Middelhavet: 1) Tyrkiet. 2) Libanon. 3) Egypten. 4) Libyen. 5) Tunesien. 6) Algeriet og 7) Marokko. De pågældende lande er udvalgt for at vise, hvordan EU's politik på området udvikler sig.

\section{EU-Tyrkiet}

Relationerne mellem EU og Tyrkiet på det migrant- og flygtningepolitiske område var indtil 2016 præget af, at Tyrkiet var det centrale land i fødekæden til den såkaldte balkanrute, som gik fra Tyrkiet over Grækenland og gennem en række balkanlande (som regel Makedonien, Serbien, Ungarn og/eller Kroatien) og endte i Østrig og Tyskland. På de enkelte dele af denne rute opkrævede menneskesmuglere

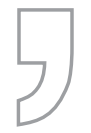

EU og Tyrkiets aftale i 2016 angående en inddæmning af migrant- og flygtningekrisen er sandsynligvis det tydeligste eksempel på, at EU har taget en kurs mod et mere realistisk pengediplomati. 
oftest en pris af migranterne og flygtningene for at bringe dem videre.

EU og Tyrkiets aftale i 2016 angående en inddæmning af migrant- og flygtningekrisen er sandsynligvis det tydeligste eksempel på, at EU har taget en kurs mod et mere realistisk pengediplomati.

Den 18. marts 2016 blev EU's statsog regeringschefer på den ene side og Tyrkiet på den anden side enige om en fælles erklæring, som skulle standse den ulovlige migrantstrøm fra Tyrkiet og ind i EU, sikre forbedrede modtagefaciliteter for flygtninge i Tyrkiet og åbne for organiseret, sikker og lovlig adgang for syriske flygtninge ind i EU.

Forud for aftalens indgåelse havde især Tyskland og den tyske forbunds- kansler, Angela Merkel, været meget aktive for at gøde jorden for en aftale, hvilket naturligvis skyldtes, at i særdeleshed Tyskland var endemålet for de flygtninge, der tog vejen fra Tyrkiet over Ægæerhavet til Grækenland og derfra videre ad balkanruten.

To år efter aftalen var den ulovlige migration ind i EU fra Tyrkiet 97 pct. lavere end i perioden før, den fælles aftale blev operationel. Også antallet af omkomne i forsøget på at nå til et EUland fra Tyrkiet aftog dramatisk. Som kompensation for de tyrkiske myndigheders samarbejde med at huse de mange syriske flygtninge har man fra EU's side støttet Tyrkiet med meget store beløb. I slutningen af 2017 faldt den første rate på tre mia. euro (ca. 22 mia. kroner) til betaling.

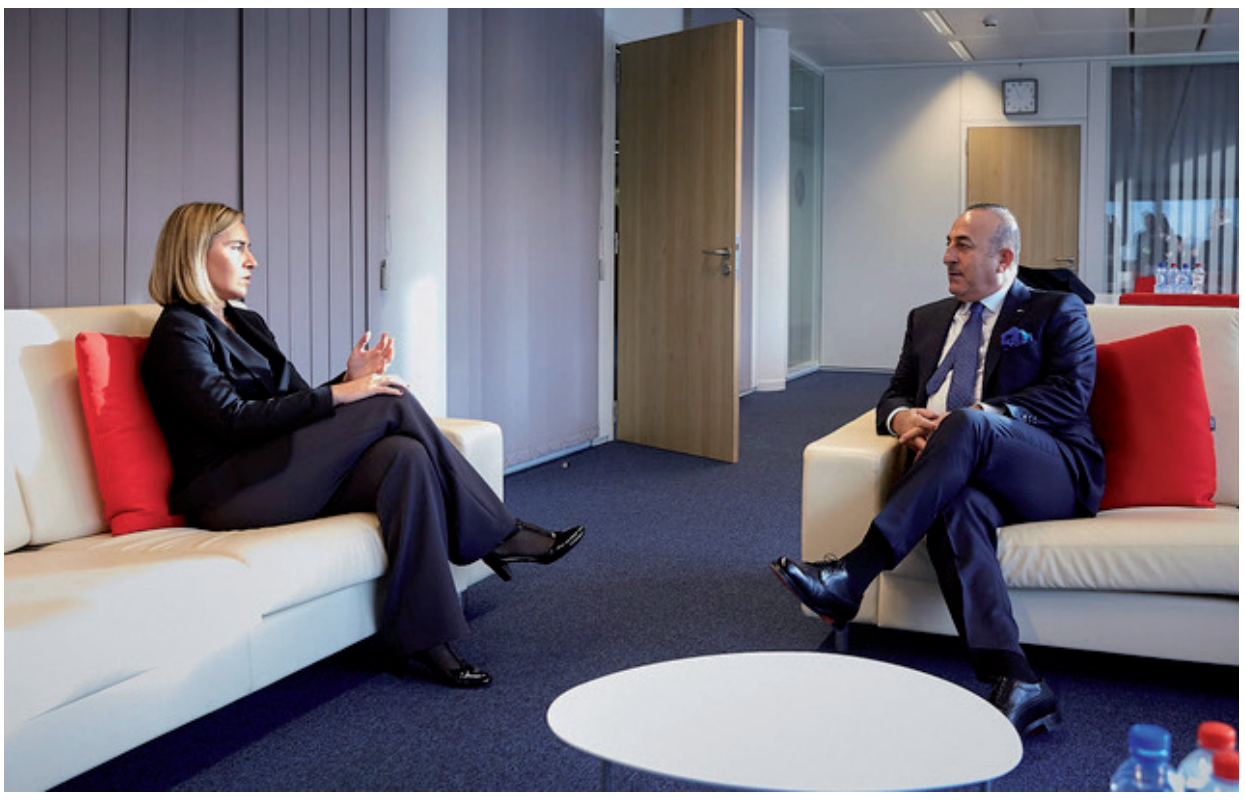

FOTO : European External Action Service via Flickr

EU's udenrigschef Federica Mogherini og Tyrkiets udenrigsminister Mevlut Cavusoglu. 6. december 2016 
Tyrkiet har ifølge Europa-Kommissionen "fulgt op på landets forpligtelser [ifølge aftalen mellem EU og Tyrkiet] for at optrappe foranstaltningerne rettet mod menneskesmugling, og man har samarbejdet tæt [med EU] med henblik på genhusning og returnering."

Europa-Kommissionen ser selv aftalen med Tyrkiet som en 'game changer'. Den har vist, at man takket være samarbejdet med de tyrkiske myndigheder har kunnet bryde menneskesmuglernes 'forretningsmodel'. Mens 10.000 dagligt krydsede Ægæerhavet fra Tyrkiet til en af de græske øer tæt på den tyrkiske kyst i oktober 2015, var dette tal faldet til 80 i 2018. Antallet af omkomne i Ægæerhavet faldt fra 1.175 i de 20 måneder før EU-Tyrkiet-erklæringen til 130 efter.

Det indebærer, at Europa-Kommissionen i april 2018 kunne foretage en kontrafaktisk beregning, som indebar, at næsten en million mennesker ikke havde taget den farlige rute over Ægæerhavet, og at mere end 1.000 personer havde undgået døden i bølgerne på ruten.

Fremover skal EU ifølge aftalen bidrage med yderligere tre mia. euro til Tyrkiet, således at den samlede pengediplomatiske pris på at undgå syriske flygtninge fra Tyrkiet løber op i seks mia. euro (ca. 44 mia. kroner). Det åbne spørgsmål er, hvad der sker efter, at anden rate i EU's pengediplomati i forhold til Tyrkiet er erlagt. Vil Tyrkiet kræve yderligere betaling for at beholde de syriske flygtninge? Eller vil de kunne vende tilbage til Syrien?

\section{EU-Libanon}

Libanon er det land, som har været hårdest ramt af den syriske flygtningekrise. Landet har modtaget cirka 1,5 mio. syriske og palæstinensiske flygtninge fra Syrien, hvilket svarer til omkring 30 pct. af landets befolkning. Libanon har for en del syriske flygtninge været det foretrukne land at tage til. Libanon og Syrien var tidligere én politisk enhed, og der er stadig mange familiebånd mellem de to lande.

Siden 2011 har Europa-Kommissionen støttet de syriske flygtninge i Libanon med omkring en halv mia. euro i humanitær bistand. De er anvendt til dels direkte pengeudbetalinger med henblik på indkøb af fornødenheder. Dels er de gået til sundhedsfaciliteter, vand og sanitet. Beløbet er beskedent. Det kan realistisk tolkes som havende sin baggrund $i$, at der ikke er den store fare for, at de syriske flygtninge søger til Europa fra Libanon.

Gør de det, går ruten via Tyrkiet, som EU har en aftale med (jf. ovenfor). Set med disse EU-realistiske øjne holdes flygtningene i Libanon således tilbage via EU-Tyrkiet aftalen.

\section{EU-Egypten}

Egypten er til tider første destination på migrations- og flygtningeruten for personer med rod i Mellemøsten eller Østafrika. Ud af de cirka 220.000 personer, der er registeret af FN's flygtningeorganisation, UNHCR, er godt halvdelen fra Syrien, og resten er fra Østafrika eller Irak.

Europa-Kommissionen hjælper især de syriske flygtninge med sundhed og uddannelse, men hjælpen er ret beske- 
den og på ikke ret mange mio. euro. Det kan skyldes, at der ikke er den store fare for, at et stort antal af dem vil sætte sig ud i menneskesmuglernes både og sejle fra Egypten og til Europa. Dertil er det egyptiske grænsepoliti trods korruption og lignende alligevel for effektivt. for etablering af et modtagecenter for migranter og flygtninge.

\section{EU-Libyen}

Også i forhold til Libyen har EU ytret ønske om at etablere et eller flere modtagecentre for migranter og flygtninge i landet. Meningen skulle være, at man i disse centre kunne få behandlet sin ansøgning om at få adgang til Europa. om betalingens størrelse, og uvilligheden kan være et forsøg på at tale prisen op.

I forhold til Egypten har EU imidlertid undersøgt muligheden for at etablere et modtagecenter for migranter og flygtninge i landet. Det er de egyptiske politiske beslutningstagere dog ikke umiddelbart indstillet på. Den 1. juli 2018 fortalte formanden for det egyptiske parlament, Ali Abdel Aal, den tyske avis Welt am Sontag, at modtagecentre i Egypten 'ville stride mod landets love og forfatning.

Også den egyptiske udenrigsminister har flere gange afslået ideen om at etablere EU-modtagecentre i Egypten. Suzy Nashed, der er medlem af det egyptiske parlaments juridiske udvalg, har forklaret det således: "Egypten har fuld suverænitet over sit landområde, og landet bør ikke være en del af en EU-plan [for migranter og flygtninge]. Endnu vigtigere er det, at sådanne centre ville stride mod bestemmelserne i den egyptiske forfatning, som forbyder, at der etableres flygtningecentre, der skal fungere isoleret fra det øvrige samfund."

Sandsynligvis vil Egypten ikke kunne være en del af en realistisk EU-plan
Libyens premierminister, Fayez el-Sarray, har imidlertid i juli 2018 udtalt, at Libyen ikke ønsker at have et EU-modtagecenter placeret inden for landets grænser. Til Bild Zeitung udtalte han da: "Vi er stærkt imod Europas officielle ønske om, at vi skal tage os af de illegale migranter, som EU ikke ønsker at modtage."

EU's udenrigsministre har i stedet kraftigt støttet det libyske grænsepoliti med uddannelse og udstyr, hvilket har haft effekt i forhold til menneskesmugleraktiviteten. Muligvis er villigheden eller uvilligheden til at etablere modtagecentre i Libyen et spørgsmål om betalingens størrelse, og uvilligheden kan være et forsøg på at tale prisen op på 'tyrkisk niveau' for at oprette et EU-modtagecenter i landet.

Samtidig har EU forsøgt at støtte og iværksætte initiativer, som kan informere personer syd for Sahara om, at de skal undlade at bevæge sig ud på en farlig rejse til Libyen med henblik på at komme til Europa. I et vist omfang er det lykkedes. Niger har tidligere været en af 'hovedleverandørerne' af migranter til Libyen. Indtil 2016 kom 90 pct. af 
migranterne i Libyen herfra. Fra 2016 og til 2018 er antallet af migranter fra Niger til Libyen imidlertid faldet fra 300.000 til 10.000 personer på grund af bl.a. en række EU-initiativer, der både hjælper med jobskabelse i Niger, og som informerer om risiciene ved at forsøge at komme til Europa.

EU har i realistisk stil betalt godt for, at myndighederne i Niger har reduceret antallet af personer, som $s \varnothing$ ger mod Libyen. EU annoncerede i slutningen af 2017, at man ville betale en mia. euro i øremærket udviklingshjælp til Niger i form af støtte til antimigrationsprojekter.

Desuden er militæret i Niger blevet støttet til at blive langt mere aktivt med hensyn til at standse menneskesmuglerne, som transporterer personer fra Niger til Libyen. Herudover betaler Tyskland, Frankrig og Italien ved siden af EU direkte til tilsvarende projekter.

Resultatet er blevet, at man i Libyen nu kan konstatere, at der er flere, der tager tilbage til Niger, end der er personer, som arriverer i Libyen fra Niger. 'Niger er blevet vor bedste allierede i regionen', har EU's ambassadør i landet, Raul Mateus Paula, konstateret.

Ifølge visse kilder er arbejdsløsheden og kriminaliteten i Niger imidlertid også steget efter, at færre unge kan tage turen til Libyen og eventuelt videre.

\section{EU-Tunesien}

Tunesiens EU-ambassadør, Tahar Cherif, nævnte i juni 2018, at spørgsmålet om etablering af et eventuelt EU-modtagecenter for migranter og
Igen ses det $i$ ordlyden af afvisningen af at etablere et modtagecenter, at spørgsmålet om økonomiske midler er helt afgørende. Det er således implicit $i$ begrundelsen, at hvis man de tilstrækkelige midler stillet rådighed, ville nmodningen muligvis blive besvaret anderledes.

flygtninge var blevet taget op under den tunesiske regeringsleders besøg i Tyskland i foråret 2018.

Vedkommende havde svaret 'nej' til anmodningen med den begrundelse, at Tunesien hverken havde kapaciteten eller midlerne til at organisere disse modtagecentre. Igen ses det i ordlyden af afvisningen af at etablere et modtagecenter, at spørgsmålet om økonomiske midler er helt afgørende. Det ligger således implicit i begrundelsen, at hvis man fik de tilstrækkelige midler stillet rådighed, ville anmodningen muligvis blive besvaret anderledes.

Med hensyn til personer fra Tunesien er der overvejende tale om migranter (der er kun yderst få egentlige flygtninge), som kommer sydfra i Afrika. Det drejer sig om et stigende antal tunesiske statsborgere, som kommer fra landets sydlige provinser, hvor arbejdsløsheden er stor og stigende. Derfor har mange familier i disse områder gjort det, at de sparer penge sammen til via menneskesmuglere at kunne sende én søn på vej til Europa, hvorfra de håber, at han efterfølgende kan sende penge tilbage.

De fleste unge tunesere vil i den forbindelse helst til det nordlige Europa, hvor der findes store tunesiske diasporasamfund i mange af storbyerne, og hvor de håber at kunne få job og støtte i den første tid. Disse unge tunesere til- 
stræber derfor både en 'første bevægelse' til et sydeuropæisk land og derefter en 'anden bevægelse' videre nordpå.

Deres interesse i ikke at blive registret i fx Italien er således sammenfaldende med de italienske myndigheders. Ønsket om en 'anden bevægelse' forudsætter imidlertid ikke kun ikkeregistrering i Italien men også, at de uden det store besvær og grænsekontrol kan bevæge sig nordpå. Sidstnævnte er vanskeliggjort af den midlertidigt etablerede interne grænsekontrol mellem Schengenlandene.

\section{EU-Algeriet}

I Algeriet har man konstateret, at flere illegale migranter kommer til landet i kraft af, at EU har gjort det sværere at nå til Europa. Algeriet er i den situation, at landet har en $2.500 \mathrm{~km}$ lang grænse mod syd til Mali og Niger, og man modtager mange illegale migranter ad denne vej.

Det er også grunden til, at Algeriet sammen med andre nordafrikanske lande som Tunesien, Libyen og Egypten har nægtet at underskrive protokollen om fri bevægelighed for personer, som er knyttet til Den Afrikanske Unions kontinentale frihandelsaftale.

Bl.a. også fordi man således ikke er juridisk forpligtet til at beholde afrikanske migranter, har Algeriet siden 2015 kunnet repatriere ca. 27.000 personer, som oprindeligt kom fra lande syd for Sahara. Niger har i den forbindelse protesteret mod behandlingen af dets borgere i Algeriet, og regeringen i Guinea har ligefrem tilbagekaldt landets ambassadør i protest mod behandlingen af migranterne fra Guinea i
Algeriet. Algeriet blev i den forbindelse også anklaget for racistisk behandling af guineanerne.

Algeriets ambassadør i Belgien udtalte i marts 2018, at man vis-á-vis indvandringen fra Afrika gerne ville advare om, at EU's stramninger af immigrationspolitikken medførte, at landene i Nordafrika pludselig blev de mest attraktive lande for migranterne sydfra i Afrika. Samtidig tyder udtalelserne på, at EU's nye realistiske linje på området virker.

\section{EU-Marokko}

Marokko har på det seneste undladt at tilbageholde illegale flygtninge og migranter, som forsøger at komme ind i Spanien. Hvis den situation skal ændres, er prisen sandsynligvis flere midler til Marokko, hvilket EU ifølge Europa-Kommissionen er parat til at honorere.

Det er imidlertid uklart, hvad der menes med 'flere midler'. I juli 2018 øremærkede EU 55 mio. euro til Marokko og Tunesien. De skal anvendes til at hjælpe den marokkanske regering med at uddanne og udstyre grænsepolitiet i stil med, hvad man har gjort i Libyen.

Ifølge Europa-Kommissionen er de 55 mio. euro kun første skridt i et større initiativ, der også indebærer, at de to nordafrikanske lande må acceptere at modtage migranter, som befinder sig på både i Middelhavet, men som er sejlet ud fra de to lande.

Endnu flere midler til bl.a. Marokko forventes at tilflyde landet efter EU-beslutninger i efteråret 2018 og igen $\mathrm{i}$ 2019, og de skyldes ikke mindst et pres fra Spanien på grund af det stigende 
antal migranter, der søger til de spanske kyster og til de spanske enklaver Ceuta og Melilla på den nordafrikanske kyst. Spanien presser således på for en aftale med Marokko på samme måde, som Tyskland gjorde i forhold til Tyrkiet.

Den spanske regering mener, at støtten til Marokko er alt for lille til, at landet for alvor vil tage fat på at begrænse stigningen i migrationen til Spanien. Derfor ønsker Spanien, at EU hjælper Marokko på samme måde og med de samme midler, som man hjælper Tyrkiet.

I den forbindelse henviser Spanien til, at antallet af migranter og flygtninge til Spanien fra Marokko voksede 100 pct. i 2017 i forhold til året før. I 2018 er det yderligere vokset i forhold til 2017. Samtidig mener Marokko imidlertid, at man allerede gør meget, idet man alene i første halvår af 2018 har standset 25.000 personer, som ville videre til Europa. Endvidere peger man på, at det stigende antal afrikanere fra syd for Sahara, som søger til Marokko, hænger sammen med, at langt færre kan komme til Europa via Libyen, fordi EU's initiativer begynder at virke i dette land.

Ifølge tal fra Den Internationale Organisation for Migration er antallet af migranter og flygtninge, som dukker op på den spanske kystlinje tredoblet fra 2016 til omkring 22.000 i 2017. De er ikke mindst blevet sejlet ud i menneskesmuglerbåde fra Marokko. Det er årsagen til presset fra Spanien.

\section{EU's realisme?}

EU's kommissær for området, Dimitris Avrampoulos, har flere gange fremhævet, at EU ønsker at 'intensivere samarbejdet' med Algeriet, Egypten, Libyen, Tunesien, Niger og Marokko.

I EU-regi cirkulerer der fortsat en idé om etablering af egentlige modtagecentre for migranter og flygtninge i et eller flere nordafrikanske lande, hvilket støttes af ikke mindst Tyskland, Italien og Spanien. Ideen er imidlertid stadig på et forholdsvis skitseagtigt stade, idet en række spørgsmål af både politisk, økonomisk, praktisk og juridisk art er uafklarede. Det gælder også spørgsmålet om, hvorvidt migranter på skibe $\mathrm{i}$ et EU-medlemslands farvand ville kunne fragtes til et sådant modtagecenter.

Samtidig har ingen af de nordafrikanske lande på forhånd meldt sig som værende villige til at huse et modtagecenter for migranter og flygtninge drevet af EU. På sin side har EU heller ikke fremsendt en officiel anmodning herom. Der har alene været tale om uofficielle sonderinger.

Meget tyder også på, at kun ved hjælp af meget betydelige beløb til landene, hvorfra migranterne og flygtningene kommer, vil man ikke kunne undgå dem inden for EU's grænser. En strengere grænsekontrol via Frontex/ European Border and Coast Agency er med til at afhjælpe presset, men det letter det ikke afgørende. Det gør kun 
betalinger à la dem, der gives til Tyrkiet, og som minder om, hvad både de romerske og byzantinske imperier blev nødt til at betale barbarernes ledere uden for imperiegrænserne for at undgå, at meget store grupper ville trænge ind over grænserne.

Sandsynligvis er det netop, hvad både den marokkanske, den tunesiske og den libyske regering tragter efter, og som - hvis den kom på niveau med betalingerne i EU-Tyrkiet aftalen - ville medføre en anderledes velvillighed i forsøget på at begrænse antallet af migranter og flygtninge til EU gennem etablering af egentlige modtagelsescentre $i$ et eller flere lande.

EU må derfor være villig til at allokere betydelige midler til de lande, som - hvis den økonomiske overførsel var på tyrkisk niveau - ville være villige til at huse et EU-modtagecenter. Hvis man fra EU's side vil finde et svar på migrant- og flygtningespørgsmålet, som efter alt at dømme efterspørges af vælgerne i EU-landene, må man være mere realistisk i den betydning af ordet, som blev introduceret i artiklens indledning. 